RESEARCH ARTICLE

\title{
Effect of Pre and Early Post Emergence Herbicides on Weed Control in Irrigated Blackgram (Vigna mungo L.)
}

\author{
Sukumar $J^{\star 1}$ and Kunjammal $P^{2}$ \\ ${ }^{* 1}$ Rathanavel Subaramaniyam - Krishi Vigayan Kendra, Triunelveli - 627852. \\ ${ }^{2}$ Department of Agronomy, Tamil Nadu Agricultural University, Coimbatore - 641003.
}

Received : $31^{\text {st }}$ January, 2020

Revised : $03^{\text {rd }}$ February, 2020

Revised : $21^{\text {st }}$ February, 2020

Accepted : $05^{\text {th }}$ March, 2020

\section{ABSTRACT}

Field experiment was conducted to find out the effect of pre-emergence $(\mathrm{PE})$ and early post-emergence (EPoE) herbicides on weed control in irrigated blackgram at College of Agricultural Technology, Kullapuram- Theni during 2015-2016. In this experiment, weed management practice of preemergence application of Pendimethalin $30 \mathrm{EC} 1.0 \mathrm{~kg}$ a.i. ha ${ }^{-1}$ at 3 days after sowing (DAS), early post-emergence application of Quizalofop ethyl@ 50 g a.i. ha ${ }^{-1}$ at 15 DAS, early post-emergence and Imazethapyr each @ $50 \mathrm{~g}$ a.i. ha ${ }^{-1}$ at 15 DAS and their combinations of Pendimethalin @ $1.0 \mathrm{~kg}$ ha $^{-1}$ at 3 DAS followed by either Quizalofop ethyl or Imazethapyr each @ $50 \mathrm{~g}$ a.i. ha ${ }^{-1}$ were tested against hand weeding twice at 20 and 40 DAS, weedy check and weed-free check as controls in randomized block design replicated thrice. Among the different weed management practices, preemergence application of Pendimethalin $1.0 \mathrm{~kg}^{2}$ a.i. ha-1 (3 DAS) followed by Imazethapyr @ 50g a.i. ha-1 as EPoE (15 DAS) recorded relatively lesser proportion of broad-leaved weeds (30.90 and 49.16\%) and higher Weed Control Efficiency (WCE) of 91.27 at 60 DAS. Application of pendimethalin 1.0 kg a.i. ha-1 PE (3 DAS) followed by Imazethapyr @ 50g a.i. ha ${ }^{-1}$ as EPoE (15 DAS) registered significantly taller plants $(42.22 \mathrm{~cm})$, higher dry matter production(2649 $\left.\mathrm{kg} \mathrm{ha}^{-1}\right)$, more number of pods per plant (44.19), seeds per pod(5.57) and higher grain yield (1052 kg ha-1). Thus, pre-emergence application of pendimethalin $1.0 \mathrm{~kg}$ a.i. ha-1 (3DAS) followed by Imazethapyr @ 50g a.i. ha- ${ }^{-1}$ as EPoE (15DAS) recommended as effective and economic weed management practices on the basis of better weed control, crop growth, and yield of irrigated blackgram.

Keywords: Pendimethalin, Imazethapyr, Quizalofop ethyl

\section{INTRODUCTION}

Pulses are commonly known as food legumes, which are secondary to cereals in production and consumption in India. Pulses provide 25 per cent of protein requirements of the predominantly vegetarian population. Pulses play an important role in Indian Agriculture as they restore soil fertility by fixing atmospheric nitrogen through their nodules. These are drought resistant and prevent soil erosion due to their deep root system and good ground coverage, and because of these good characters, pulses are called "Marvel of Nature". India is the largest producer and consumer of pulses in the world, accounting for 33 per cent of the world area and 22 per cent of world production. The productivity of pulse in India is low around 550- $625 \mathrm{kgha}^{-1}$ against $1600 \mathrm{~kg}$ in USA, $1400 \mathrm{~kg}$ in China and a world average of $900 \mathrm{~kg} \mathrm{ha}^{-1}$.

Among the grain legumes, blackgram is an *Corresponding author's e-mail: sukumaragri@yahoo.co.in ancient and well-known leguminous crop of Asia, a favorable one since it thrives better in all the seasons, and it can be grown as a sole or intercrop or fallow crop. The primary constraint in pulses production is the weed growth, which inflicts heavy losses on the crop yield by competing for essential growth factors viz., nutrients, space, light, and moisture. Weed management at the early stages of crop growth is essential in pulses since emerging of weeds in pulses begins simultaneously with the crop, leading to severe competition between the crop and weeds (Kandasamy, 2000). Being a short duration crop and initially slow growing in nature, blackgram is heavily infested with grasses, broadleaved weeds, and sedges, which compete with the crop, resulting in yield reduction (Mishra, 1997). The magnitude of reduction in yield depends upon the weed flora present, quantum of weed flora, and duration of crop-weed competition. The maximum crop weed competition in blackgram was observed $107|1-3| 36$ 
during the period of 10 to 30 days after sowing. Weed infestation causes 50 to 87 per cent yield reduction in blackgram throughout the growth period of the crop (Sardana et al., 2006).

The traditional methods of weed control viz., inter cultivation or hand weeding alone is laborconsuming, expensive and insufficient. Moreover, complete weeding during critical crop growth stages is not possible due to increased cost and scarcity of human labour. In addition, continuous rains during early crop growth stages hinder the cultural methods of weed control. Complete control of weeds cannot be achieved by using any one method or single herbicide. Under such circumstances, pre and postemergence herbicides applied in combination will control the weeds very effectively. Further herbicides and their mixtures are also now available in the market, which controls broad-spectrum weeds very effectively. Keeping these points in view, the present study was undertaken to find out the effect of chemical weed management practices on weed control and yield of irrigated blackgram.

\section{MATERIAL AND METHODS}

The field experiment was conducted during Rabi 2015-16 at the College of Agricultural Technology, Kullapuram, Theni situated in the Southern agroclimatic zone of Tamil Nadu at $10^{\circ} 5^{\prime} \mathrm{N}$ latitude and $77^{\circ} 5^{\prime} \mathrm{E}$ longitude at an altitude of $40 \mathrm{~m}$ above mean sea level. The soil of the experimental field was sandy clay loam in texture with the available nitrogen $234.26 \mathrm{~kg} \mathrm{ha}^{-1}$, phosphorus 16.76 $\mathrm{kg} \mathrm{ha}^{-1}$, potassium $294.24 \mathrm{~kg} \mathrm{ha}^{-1}$ and organic carbon content $0.30 \%$. The experiment was laid out in a randomized block design.Pre-emergence application of pendimethalin 30 EC $1.0 \mathrm{~kg}$ a.i. ha ${ }^{-1}$ at 3 days after sowing (DAS), early post-emergence application of quizalofop ethyl@ 50 g a.i. ha-1 at 15 DAS, early post-emergence application of imazethapyr @ 50 $g$ a.i. ha ${ }^{-1}$ at 15 DAS and their combinations of pendimethalin @ $1.0 \mathrm{~kg} \mathrm{ha}^{-1}$ at 3 DAS followed by either quizalofop ethyl or imazethapyr each @ $50 \mathrm{~g}$ a.i. ha ${ }^{-1}$ were tested against hand weeding twice at 20 and 40 DAS, weedy check and weed-free check as control. Herbicides were sprayed as per the treatment schedule. Blackgram was sown at $20 \mathrm{~kg}$ $\mathrm{ha}^{-1}$ seed rate at $30 \times 10 \mathrm{~cm}$ spacing. Immediately after sowing, irrigation was given for ensuring proper germination and establishment of the crop. Observations on weeds dynamics, plant height, yield attributing characters viz., pods per plant, seeds per pod, and grain yield were recorded. Weed count was recorded by using $0.25 \mathrm{~m}^{2}$ quadrate at four places in each plot and expressed as numbers $\mathrm{m}^{-2}$. Weed control efficiency was worked out on 20,40 , and 60 DAS and expressed as the percentage reduction in weed density due to weed management practices over control. Economics of weed management was worked out by using the current market price of inputs and blackgram grain. All the recorded data were analyzed statistically, as per the method suggested by Gomez and Gomez (2010).

\section{RESULTS AND DISCUSSION}

\section{Weed flora}

The weed flora included five kinds of grass, one sedge and eight broad-leaved weeds. The results revealed the dominance of broad-leaved weeds in the experimental field. The major graminaceous weeds were Cynodon dactylon, Dactyloctenium aegyptium and Panicum javanicum. Along with common Cyperaceae weed Cyperus rotundus, six families of broad-leaved weeds were present in the experimental field, of which Trianthema portulacastrum, Parthenium hysterophorus, Boerhaavia diffusa and Euphorbia geniculata were important.

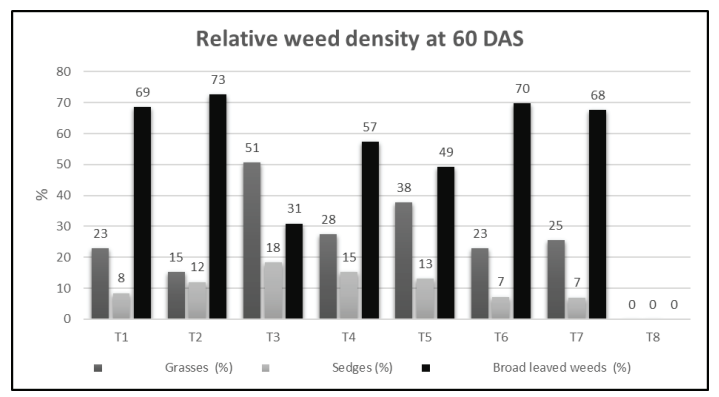

Figure 1. Effect of weed control treatments on Relative weed density (\%)

Among the individual weed species, Trianthema portulacastrum was found to be predominant. Similalry, a wide spectrum of weeds in blackgram fields was reported by many workers (Veeraputhiran et al., 2008).

\section{Relative density}

The observation on the weed shift in weed population in irrigated blackgram through its growth stages revealed that though the early postemergence application of quizalofop ethyl at 15 DAS kept the grassy weed population low, however, the broad-leaved weeds were low in treatments applied with imazethapyr. The shift in the proportion of weeds due to weed control treatments was evident at 60 DAS. All the weed control treatments except the plots applied with quizalofop ethyl @ 50 g a.i. ha ${ }^{-1}$ recorded a higher proportion of grasses as compared to weedy check indicating its efficacy in controlling grasses. Regarding sedges at 60 DAS, hand weeded plots i.e., hand weeding twice at 20 and 40 DAS, recorded a lesser proportion of sedges (Figure 1). In case of broad-leaved weeds application of imazethapyr @ $50 \mathrm{~g}$ a.i. ha-1 ${ }^{-1}$ reduced the proportion of broad-leaved weeds. It is interesting to note that an increase in proportion of grasses 
compensates for this reduction. These results showed that there was a marked change in the weed species from broad-leaved weeds to grasses and sedges in treatments that involves imazethapyr.

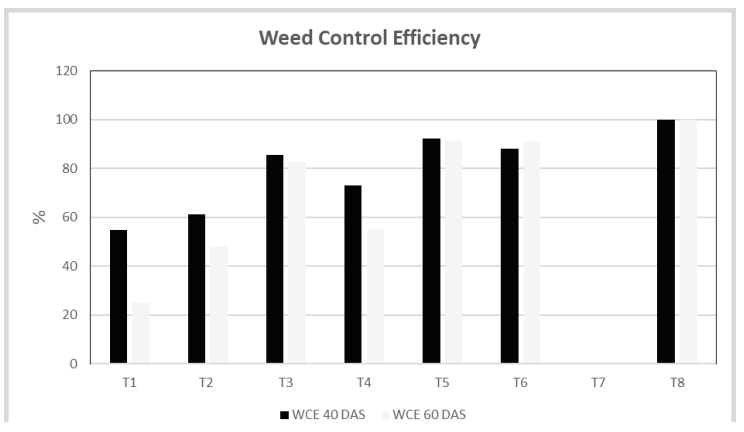

Figure 2. Effect of weed control treatments on weed control efficiency (\%)

T1: Pendimethalin $1.0 \mathrm{~kg}$ a.i. ha ${ }^{-1}$ as PE (3 DAS),T2: Imazethapyr @ $50 \mathrm{~g}$ a.i. ha-1 as EPOE (15 DAS),T3: - Quizalofop ethyl @ $50 \mathrm{~g}$ a.i. ha as EPOE (15DAS),,T4: Pendimethalin $1.0 \mathrm{~kg}$ a.i. ha ${ }^{-1}$ as PE (3 DAS) + Quizalofop ethyl @ $50 \mathrm{~g}$ a.i. ha ${ }^{-1}$ as EPOE (15DAS),,T5: Pendimethalin $1.0 \mathrm{~kg}$ a.i. ha-1 PE (3DAS) + Imazethapyr @ 50g a.i. ha ${ }^{-1}$ as EPOE (15DAS) T6: Hand weeding twice at 20 and 40 DAS, T7: Weedy check and T8: Weed free check * Recommended dose of fertilizer (RDF): 25 $\mathrm{kg} \mathrm{N}, 50 \mathrm{~kg} \mathrm{P}_{2} \mathrm{O}_{5} \& 25 \mathrm{~kg} \mathrm{~K}_{2} \mathrm{O}$ ha $^{-1}$

Application of imazethapyr @ 50 g a.i. ha-1 with pre-emergence application of pendimethalin 1.0 $\mathrm{kg}$. $\mathrm{ha}^{-1}$ registered relatively lesser proportion of broad-leaved weeds (30.90 per cent) indicating their efficiency against broad-leaved weeds, which were the predominant group of weeds present in the experimental field. However, this reduction was compensated by a proportionate increase in grasses and sedges in these treatments. Among them, pre-emergence application of pendimethalin $1.0 \mathrm{~kg}$ a.i. ha-1 PE (3DAS) followed by Imazethapyr @ 50 g a.i. ha-1 recorded relatively lower weed density. Rao (2010) recorded effective control of broad-leaved weeds through the combination of preemergence application of pendimethalin $1.0 \mathrm{~kg} \mathrm{ha}^{-1}$ with imazethapyr @ 50 g a.i. ha ${ }^{-1}$.

\section{Weed control efficiency}

Weed control efficiency (WCE), which indicates the magnitude of effective reduction of weed dry matter by weed control treatments over unweeded control, was highly influenced by different treatments (Figure 2). At 40 and 60 DAS, WCE was higher (92.10 and 91.27 per cent, respectively) with the weed management practices of pre-emergence application of Pendimethalin $1.0 \mathrm{~kg}$ a.i. ha-1 PE (3 DAS) followed by Imazethapyr @ 50 g a.i. ha ${ }^{-1}$ at 15 DAS. This might be due to less weed DMP because of the low weed population by better weed control. However, this was comparable with Hand weeding twice at 20 and 40 DAS which registered WCE of $90.98 \%$. This might be due to the greater reduction of a wide spectrum of weeds at early stages of crop growth, which reduced the weed biomass. Sakthi and Velayutham (2018) reported a similar finding. Raman and
Krishnamoorthy (2005) observed that the application of pendimethalin @ $1.0 \mathrm{~kg} \mathrm{ha}^{-1}$ as pre-emergence at 3 DAS with one hand weeding at 20 DAS recorded significantly lower weed number, weed dry weight and higher WCE in mungbean. Dhaker et al. (2010) also reported that hand weeding at later stages recorded higher WCE.

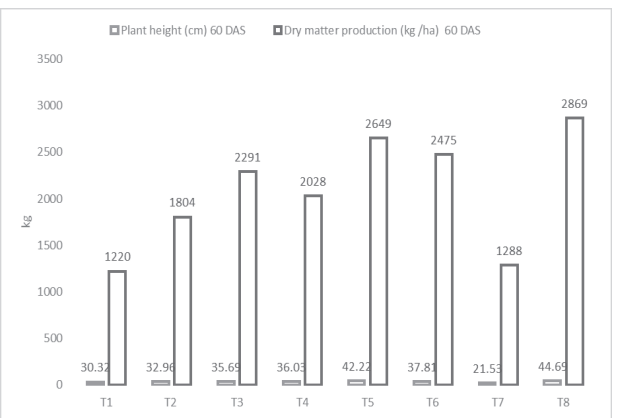

Figure 3. Effect of weed control treatments on Plant height (cm) and Dry Matter production (kg/ha)

Thus, it is evident from the data that the WCE with herbicide treatments, in general, was higher with pre-emergence herbicides Pendimethalin $1.0 \mathrm{~kg}$ a.i. ha-1 PE (3 DAS) followed by Imazethapyr @ 50 g a.i. ha ${ }^{-1}$ at 15 DAS, the efficiency is higher at 60 DAS.

\section{Growth attributes}

Pre-emergence application of Pendimethalin 1.0 kg a.i. ha ${ }^{-1}$ PE (3DAS) followed by Imazethapyr @ 50 g a.i. ha-1 at 15DAS recorded significantly taller plants $(42.22 \mathrm{~cm})$ and higher dry matter production (DMP) $(2649 \mathrm{~kg} / \mathrm{ha})$ (Figure 4). However, this was comparable with Hand weeding twice at 20 and 40 DAS.

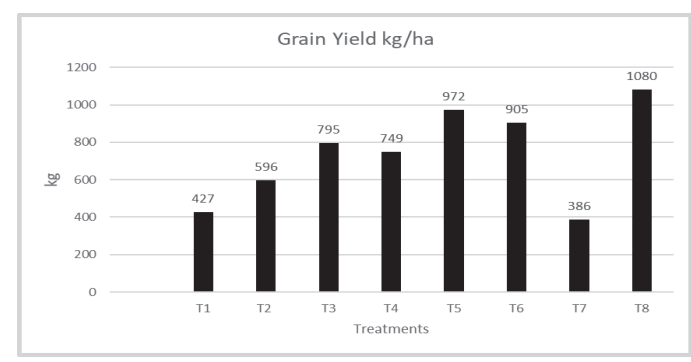

Figure 4. Effect of weed control treatments on grain yield (kg/ha) of blackgram

T1: Pendimethalin $1.0 \mathrm{~kg}$ a.i. ha ${ }^{-1}$ as PE (3 DAS),T2: Imazethapyr @ $50 \mathrm{~g}$ a.i. ha-1 as EPOE (15 DAS),T3: Quizalofop ethyl @ $50 \mathrm{~g}$ a.i. ha ${ }^{-1}$ as EPOE (15DAS),, T4: Pendimethalin $1.0 \mathrm{~kg}$ a.i. ha-1 as PE (3 DAS) + Quizalofop ethyl @ 50 g a.i. ha ${ }^{-1}$ as EPOE (15DAS),,T5: Pendimethalin $1.0 \mathrm{~kg}$ a.i. ha-1 PE (3DAS) + Imazethapyr @ 50g a.i. ha-1 as EPOE (15DAS) T6: Hand weeding twice at 20 and 40 DAS ,T7: Weedy check and T8: Weed free check * Recommended dose of fertilizer (RDF): 25 $\mathrm{kg} \mathrm{N}, 50 \mathrm{~kg} \mathrm{P}_{2} \mathrm{O}_{5} \& 25 \mathrm{~kg} \mathrm{~K}_{2} \mathrm{O}$ ha $^{-1}$

Plant height and DMP of blackgram were favorably increased with the weed management practice of pre-emergence application of Pendimethalin $1.0 \mathrm{~kg}$ a.i. ha-1 PE (3DAS) followed by Imazethapyr @ $50 \mathrm{~g}$ a.i. ha ${ }^{-1}$ at $15 D A S$ and hand weeding twice compared 
to the weedy check. Weedy check plots consistently recorded the lower plant height and DMP (21.53 $\mathrm{cm}$ and $1288 \mathrm{~kg} / \mathrm{ha}$ ) of crop at all the stages due to the competition exerted by weeds. Similar results of increased DMP of blackgram with the application of Pendimethalin $1.0 \mathrm{~kg}$ a.i. ha-1 PE (3DAS) followed by Imazethapyr @ $50 \mathrm{~g}$ a.i. ha ${ }^{-1}$ at 15DAS and hand weeding twice due to less weed dry weight and density was reported by Rao, 2010. Increased plant height, leaf area index in these treatments favored them to produce high dry matter. This was possible because of higher WCE and higher availability of plant nutrients, moisture, and sunlight as well as minimum competition from weeds.

\section{Yield attributes and yield}

The number of pods per plant in blackgram, was higher with pre-emergence application of Pendimethalin $1.0 \mathrm{~kg}$ a.i. ha ${ }^{-1}$ PE (3DAS) followed by Imazethapyr @ $50 \mathrm{~g}$ a.i. ha ${ }^{-1}$. The weed control treatments did not influence the number of seeds per pods and test weight, since these characters are largely decided by their genetic potential as reported by Gaganpreet Kaur et al. (2010). A higher mean grain yield of $972 \mathrm{~kg} \cdot \mathrm{ha}^{-1}$ was obtained with the application Pendimethalin 1.0 kg a.i. ha-1 PE (3DAS) followed by Imazethapyr @ 50 ga.i. ha-1 (Fig. 4). This might be due to the broad-spectrum control of weeds by the herbicides during early stages resulted in lesser weed competition that favored better growth and yield parameters and grain yield of blackgram. Between the herbicides used pendimethalin, recorded higher grain yield than imazethapyr ethyl at all the levels. Better weed control and higher grain of chickpea due to the application of imazethapyr was reported by Kachhadiya et al. (2009).

\section{CONCLUSION}

An integrated weed management practice of Pre-emergence application of pendimethalin 1.0 kg a.i. ha-1 (3 DAS) followed by Imazethapyr @ 50 $\mathrm{g}$ a.i. ha ${ }^{-1}$ can keep the weed density and growth below the economic threshold level and increase the yield and economics of irrigated blackgram during the rabi season. Weed management practice of pre-emergence application of pendimethalin 1.0 kg a.i. ha-1 (3 DAS) followed by Imazethapyr @ 50 g a.i. ha ${ }^{-1} 15$ DAS to blackgram can be recommended as alternative weed management practice based on better weed control, crop growth and yield of blackgram.

\section{REFERENCES}

Dhaker, S.C., S.L. Mundra and V. Nepalia. 2010. Effect of weed management and sulphur nutrition of productivity of soybean (Glycine max (L.) Merril). Indian J. Weed Sci., 42 (3\&4): 232-234.

Gomez, K.A. and A.A. Gomez. 2010. Statistical Procedures for Agricultural Research. Wiley India Pvt. Ltd., New Delhi, India.

Gaganpreet Kaur, H.S. Brar and Guriqbal Singh. 2010. Effect of Weed Management on Weeds, Nutrient Uptake, Nodulation, Growth and Yield of Summer Mungbean (Vigna radiata). Indian J. Weed Sci., 42 (1\&2): 114-119.

Kachhadiya, S.P., Savaliya, J.J. Bhalu, V.B. Pansuriya A.G. and Savaliya, S.G. (2009). Evaluation of new herbicides for weed management in chickpea (Cicer arietinum). Legume Res., 32 (4): 293-297.

Kandasamy, O.S. 2000. Cost-effective weed management strategies in pulse production. In: Proc. of CASA on Recent advances in pulse production technology, TNAU, Coimbatore. Sep.13 Oct.30, Pp.116-119. L.). Legume Res., 32 (4): 293-297.

Mishra, J.S. 1997. Critical period of weed competition and losses due to weeds in major field crops. Farmer and Parliament XXXIII: 19-20.

Raman, R. and R. Krishnamoorthy. 2005. Nodulation and yield of mungbean [ Vigna radiata $(L)$ ] influenced by integrated weed management practices. Legume Res., 28 (2):128-130.

Rao, A.S. 2010. Evaluation of post-emergence herbicides of Cuscuta control in blackgram [Vigna mungo (L) Hepper]. The Andhra Agric. J., 57 (3): 290-291.

Sakthi and Velayutham.2018. Effect of pre and early post-emergence herbicides on weeds and productivity of blackgram under irrigated conditions. Madras Agric. J., 105 (1-3): 16-19.

Veeraputhiran, R., S. Srinivasan and C. Chinnusamy. 2008. Evaluation of post-emergence herbicide and its time of application on blackgram under rice fallow condition. Madras Agric. J., 95 (7-12): 376-379.

Virender Sardana, Sukhvinder Singh and Parvender Sheoran. 2006. Efficacy and economics of weed management practices in blackgram (Vigna mungo L.) under rainfed conditions. Indian J. Weed Sci., 38 (1 \& 2): 77-80. 